\title{
The Effect of Nicotiana glauca Leaf Extract on the Liver and Lung of Female Albino Mice: Physiological and Histopathological Studies
}

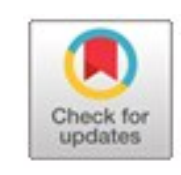

\author{
Salmin Amhamed Omar ${ }^{1 *}$, Abdalla I. Mohamed ${ }^{1}$, Fatima Amhamed Omar ${ }^{2}$, SoadAlwerfali $^{1}$ \\ ${ }^{1}$ Zoology Department, Faculty of Science, Benghazi University Benghazi Libya \\ ${ }^{2}$ Pharmacology and Toxicology Department, Faculty of Pharmacy, Benghazi University Benghazi \\ Libya
}

Received: 01 September 2019 / Accepted: 22 August 2020

Doi: https://doi.org/10.54172/mjsc.v35i2.302

\begin{abstract}
Tobacco Nicotiana glauca is a member of the Solanaceae family, found in tropical and subtropical countries especially South America, Cuba, and Brazil, as well as in North Africa, Egypt, and Libya. $N$. glauca is known to be a highly toxic plant. The major alkaloids are anabasine and nicotine. This study was aimed to determine the proper effects of a sublethal dose of the plant on female albino mice, as well as certain histological and physiological parameters. The three sublethal concentrations, $0.25,0.50$, and $2.8 \mathrm{mg} / \mathrm{kg}$ of the water extract were tested through oral route on female mice for determination of effects such as body weight, liver and lung weight and histology, blood parameters, and blood chemistry. The results showed that reduced body weight was slightly evident in treated females. Percent decrease of liver weight/body weight and increase lung weight/body weight have reported in $2.8 \mathrm{mg} / \mathrm{kg}$ treated female mice compared to control mice. Histology of liver and lung revealed an early sign of cell damage and accumulation of cell necrosis in both the liver and lungs. The blood parameters and blood chemistry did not reveal a significant difference between control and $N$. glauca treated female mice.
\end{abstract}

Keywords: Nicotiana glauca; Female Mice; Physiology; Histopathology.

\section{INTRODUCTION}

N. glauca (tree tobacco) is a member of the Solanaceae family, which includes important crops (potato, tomato, eggplant, pepper) (Long et al., 2016). Nicotine crosses the placental barrier and has been shown to have adverse effects on male and female reproduction, fetal weight gain, and development in experimental animals and humans. It was teratogenic in studies in mice, rats, rabbits, and chickens. Developmental abnormalities of the cardiovascular system have been reported in humans (Panter et al., 1999).Pyridine, piperidine, nicotine, and nornicotine were produced from $N$. glauca, however, the major alkaloids are anabasine and less than $1 \%$ concentration of nicotine (Alder et al., 2012).Nicotine is a colorless liquid that turns amber on exposure to light. More recently, nicotine sulfate has been used as a dog-controlling agent (at approximately $285 \mathrm{mg}$ of nicotine $/ \mathrm{mL}$ ). It is also used in animal tranquilizer darts (with a strength of $240 \mathrm{mg}$ of nicotine/mL). However, its use as an insecticide has been drastically reduced (Gupta, 2016).

Anabasine is similar in both structure and effects to nicotine, but it appears to be more potent in humans despite a slower onset of action (Webb and Dalzell, 1997), and the percentage of anabasine is given as 1.3 from the dry plant and 1\% from the root (Mitchell and BreyerBrandwijk, 1962).The toxic effect of anabasine and nicotine was dose-dependent and could cause various physiological effects (Melamed et al., 2004). Clinical signs for nicotine toxicosis include tremors, weakness, and decumbency. Anabasine can also moderately inhibit acetylcholinesterase. Clinical signs include weak- 
ness, ataxia, tremor, and collapse, bulbar palsies, flexure muscle spasm, nausea, vomiting, and diarrhea. Death is usually the result of respiratory compromise, paralysis, blocking of the autonomic ganglia, and acting as a cholinesterase inhibitor (Wink, 2000). Human ingestion of $N$. glauca leaves causes neuromuscular paralysis and death, and this has been attributed to anabasine (Mellick et al., 1999).

Nicotine is rapidly absorbed from the respiratory tract, mouth, and intact skin, but is poorly absorbed from the stomach under acidic conditions since it is a strong base. After absorption, nicotine is rapidly mobilized throughout the body via the blood (Gosselin et al., 1984). In experimental animals and humans, $80-90 \%$ of absorbed nicotine is metabolized primarily in the liver, in addition to the kidney and lung. The remainder is rapidly excreted unchanged in the urine (Goodman and Gilman, 1985). The liver has been reported to be the principal site of detoxification (Schievelbein and Balfour, 1984). For example (Rotenberg, 1982) reported that in a dog, $30 \%$ of the dose excreted in the urine was cotinine and cotinine metabolites. In a rat, $25 \%$ was nicotine, whereas, $15 \%$ of the total dose was exhaled as $\mathrm{CO}_{2}$ in rats.

The rate of excretion by the kidney was found to depend on the PH of the urine.The designed study was to determine the proper effects of a sublethal dose of the plant on female albino mice as well as certain histological, and physiological parameters.

\section{MATERIALS AND METHODS}

Experimental animal: Adult female Swiss albino mice Mus Musculus were obtained from the animal house of the faculty of medicine, the University of Benghazi. These animals were reared under laboratory conditions.

The chemicals: The main chemical is the crude water extract of ( $N$. glauca) leaves of the plant for which the toxicity is to be studied.
The experimentation: Three sublethal concentrations, $0.25,0.50$, and $2.8 \mathrm{mg} / \mathrm{kg}$ of the water extract of $N$. glauca leaves were tested through oral route on female mice for the determination of effects on body and organ weight, blood parameters, blood chemistry, and organ histology (Preece, 1972). Each animal orally received the specified dose via intubation, $0.1 \mathrm{ml}$ or less depending on the bodyweight of the specified concentration using a modified syringe that can be inserted into an animal pharynx with no physical harm. Control animals were dosed with comparable volumes of distilled water alone.

Blood analysis and blood chemistry: For blood collection, the animal was anesthetized with ether and the head was severed using sharp scissors where the seeping blood was collected in vials with or without potassiumEDTA to prevent blood clotting. Between 1 to $1.5 \mathrm{ml}$ of blood volume were collected in this way. The blood was collected for the measurement of Red Blood Cell (RBC) count, White Blood Cell (WBC) count, Hemoglobin (HB), Haematocrit (HCT), Mean Cell Volume (MCV) and Blood Platelets (PLT), and measurement of urea, creatinine, sodium ions $\left(\mathrm{Na}^{+}\right)$, potassium ions $\left(\mathrm{k}^{+}\right)$, total protein and Alanine transaminase (ALT). Decapitated animals were then dissected for postmortem observation, including treated mice body weight, liver and lung weight, and histology. Organs were transferred to FAA fixative (Formalin-Acetic acidAlcohol) and kept for weighting and histological studies.

Statistical analysis: The data were subjected to one-way (ANOVA) analysis, and calculation was performed using SPSS (Sokal and Rohalf, 1969) statistical package and Microsoft office excel 2007.

\section{RESULTS}

Body weight (BW):Treated female mice's body weight did not reveal a significant difference in percent body weight increase $(\mathrm{F}=$ 
2.908, $\mathrm{P}>0.101)$ as compared to the control mice. However, treated females showed a slightly decrease percent body weight gain $(6.9400 \pm 0.975,5.6433 \pm 2.277$ and $5.190 \pm$ 1.4490 ) for $0.25 \mathrm{mg} / \mathrm{kg}, 0.5 \mathrm{mg} / \mathrm{kg}$ and 2.8 $\mathrm{mg} / \mathrm{kg}$ respectively compared to control females b. w. means (mean $=8.1267 \pm 1.363$ ) (Fig 1).

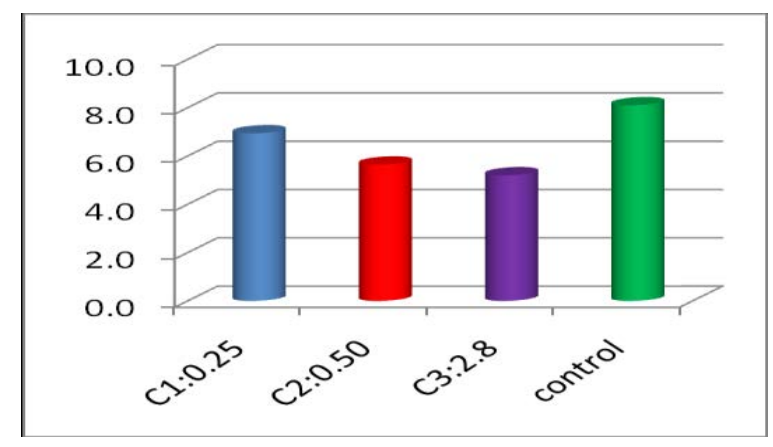

Fig 1. Shows the percent body weight $\%$ decrease $(\mathrm{BW})$ of female Swiss albino mice of $0.25 \mathrm{mg} / \mathrm{kg}, 0.5 \mathrm{mg} / \mathrm{kg}$ and $2.8 \mathrm{mg} / \mathrm{kg} \quad N$. glauca leaf water extract treated females after four weeks

\section{Organ weight:}

Liver weight (LiW/BW): The liver weight of female mice treated with $2.8 \mathrm{mg} / \mathrm{kg}$ leaf extract was found to slightly decrease $(\mathrm{F}=6.176, \mathrm{P}>0.003)$ as compared to that of control mice. Both 0.25 and 0.5 $\mathrm{mg} / \mathrm{kg}$ treated mice haven't shown any changes as compared to the liver weight of the control. Control females' mean \pm SD percent liver weight was $6.3197 \pm 0.84$ compared to that of the treated females having $6.1600 \pm 1.40,6.4573 \pm 0.57,4.5678$ \pm 1.38 for $0.25 \mathrm{mg} / \mathrm{kg}, 0.5 \mathrm{mg} / \mathrm{kg}$ and $2.8 \mathrm{mg} / \mathrm{kg}$ respectively ( Fig 2).

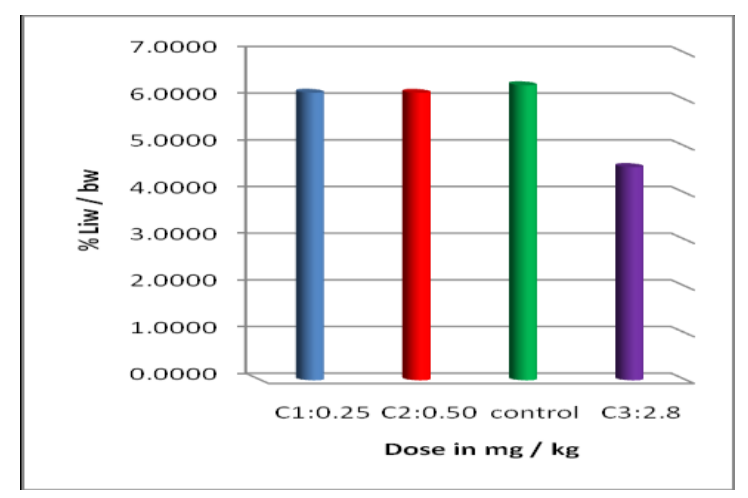

Fig 2. Shows the percent liver weight per body weight of female Swiss albino mice from control and $0.25 \mathrm{mg} / \mathrm{kg}$,
$0.5 \mathrm{mg} / \mathrm{kg}$ and $2.8 \mathrm{mg} / \mathrm{kg} \mathrm{N}$. glauca leaf water extract treated females.

Lung weight (LW/BW): The $2.8 \mathrm{mg} / \mathrm{kg}$ leaf extract treated female mice lung weight was found slightly increase $(\mathrm{F}=8.239, \mathrm{P}>0.001)$ as compared to the control mice. Whereas the other two doses haven't shown any changes as compared to the control. The mean \pm SD percent lung weight were, $1.2495 \pm 0.238$ for the $2.8 \mathrm{mg} / \mathrm{kg}$ compared to $0.8292 \pm 0.221,0.8744 \pm 0.237,0.9282 \pm 0.250$ for $0.25 \mathrm{mg} / \mathrm{kg}, 0.5 \mathrm{mg} / \mathrm{kg}$ and control respectively (Fig 3).

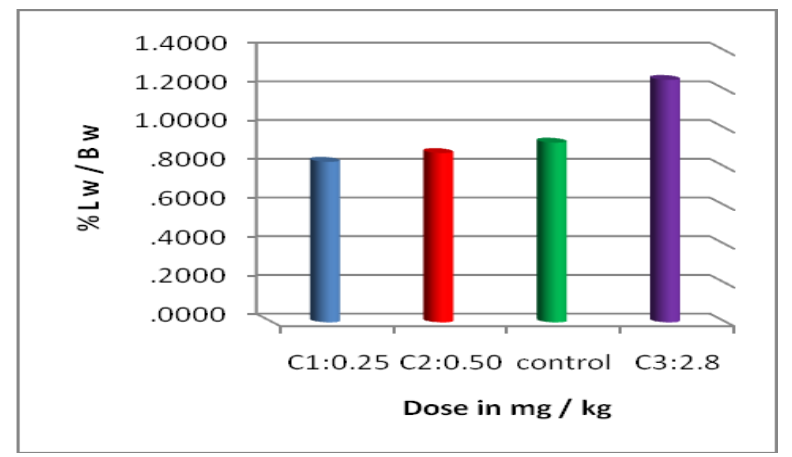

Fig 3. Shows the percent lung weight per body weight of female Swiss albino mice of control and $0.25 \mathrm{mg} / \mathrm{kg}, 0.5$ $\mathrm{mg} / \mathrm{kg}$ and $2.8 \mathrm{mg} / \mathrm{kg} N$. glauca leaf water extract treated females.

Blood parameters: The results revealed that the concentration $2.8 \mathrm{mg} / \mathrm{kg}$ had lower values than the control and the other two concentrations 0.25 and $0.5 \mathrm{mg} / \mathrm{kg}$ in all parameters except MCV. The result reflects that the higher the concentration the larger the impact (Fig. 4).

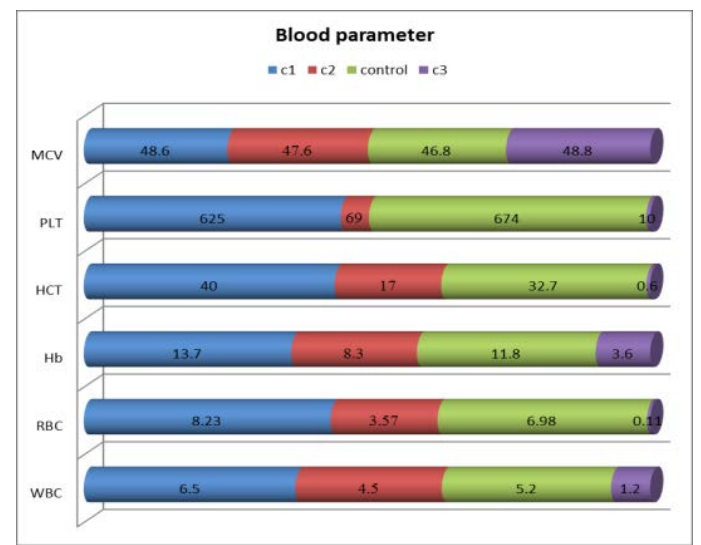

Fig. 4. Showed the blood parameter of female Swiss albino mice from control and $0.25 \mathrm{mg} / \mathrm{kg}, 0.5 \mathrm{mg} / \mathrm{kg}$ and $2.8 \mathrm{mg} / \mathrm{kg} \mathrm{N}$. glauca leaf water extract. 
Blood chemistry: The blood chemistry of the $2.8 \mathrm{mg} / \mathrm{kg}$ leaf extract has shown an elevated value of urea and a relatively high value of creatinine and a low value of $\mathrm{Na}^{+}$and $\mathrm{k}^{+}$as compared to control and the other concentrations. However, the values of $\mathrm{Na}^{+}, \mathrm{k}^{+}$, and total protein were not affected by the $N$. glauca treatment. Whereas, ALT reported higher values compared to control and 0.5 and $2.8 \mathrm{mg} / \mathrm{kg}$ (Fig. 5).

\begin{tabular}{|c|c|c|c|c|c|}
\hline \multirow[b]{2}{*}{ ALT } & & = c1 & $=\mathrm{c} 2$ & control & ac3 \\
\hline & 84 & & 53 & 73 & 61 \\
\hline t.protein & 4.6 & 4.7 & & 4.6 & 4.5 \\
\hline k+ & 7.7 & 8 & & 10 & 6 \\
\hline $\mathrm{Na}+$ & 147 & 142 & & 141 & 142 \\
\hline creat $\mathbf{0}$ & 0.3 & 0.6 & & 1.1 & \\
\hline urea & 28 & 19 & 17 & & \\
\hline
\end{tabular}

Fig. 5. Shows the blood chemistry of female Swiss albino mice from control and $0.25 \mathrm{mg} / \mathrm{kg}, 0.5 \mathrm{mg} / \mathrm{kg}$ and 2.8 $\mathrm{mg} / \mathrm{kg} N$. glauca leaf water extract.

\section{Organ Histopathology:}

\section{Liver Histopathology:}

The central vein of the liver in the control females is surrounded by normal hepatocytes and columns separated by hepatic sinusoids (Fig. 6). Whereas in $0.25 \mathrm{mg} / \mathrm{kg}$ treated mice, the central vein is surrounded by hepatocytes, but many of them contain vacuoles (hydropic degeneration) (Fig. 7).

In the $0.50 \mathrm{mg} / \mathrm{kg}$ treated mice, hepatocytes showed more vacuoles and few necrotic cells (pykontic nuclei) (Fig. 8).

In the $2.8 \mathrm{mg} / \mathrm{kg}$ treated mice, large areas of necrosis with disappeared nucleus and loss of cell boundaries were very evident (Fig.9).

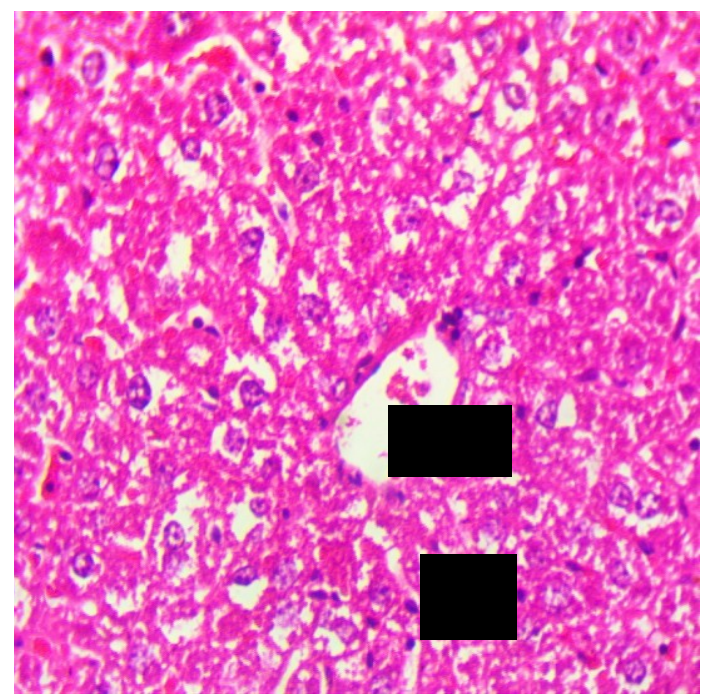

Fig. 6. Shows liver section in control. Central vein is surrounded by normal hepatocytes. (H\&E, X 400).

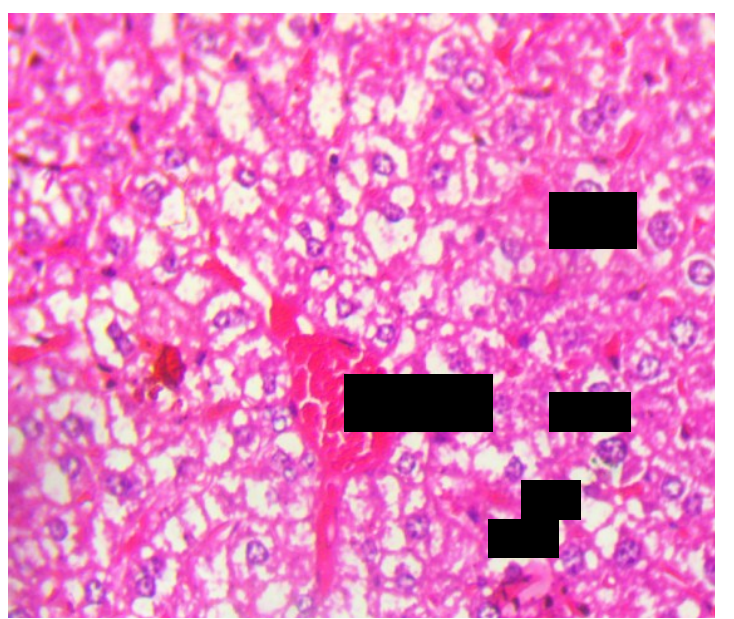

Fig. 7. Shows liver section in $0.25 \mathrm{mg} / \mathrm{kg} \mathrm{N}$. glauca treated mice. Central vein is surrounded by hepatocytes, many of them contain vacuoles. (H\&E, X 400).

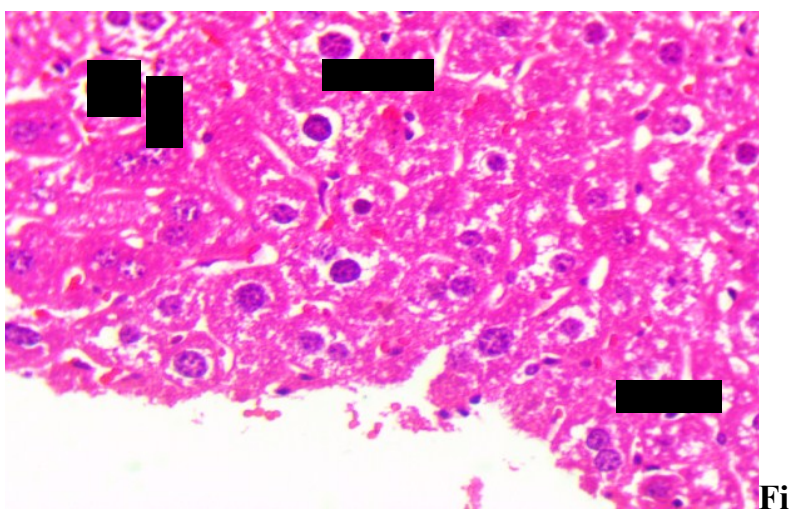

g. 8. Shows liver section in $0.50 \mathrm{mg} / \mathrm{kg} N$. glauca treated mice. Hepatocytes with more vacuoles and few necrotic cells. (H\&E, X 400). 


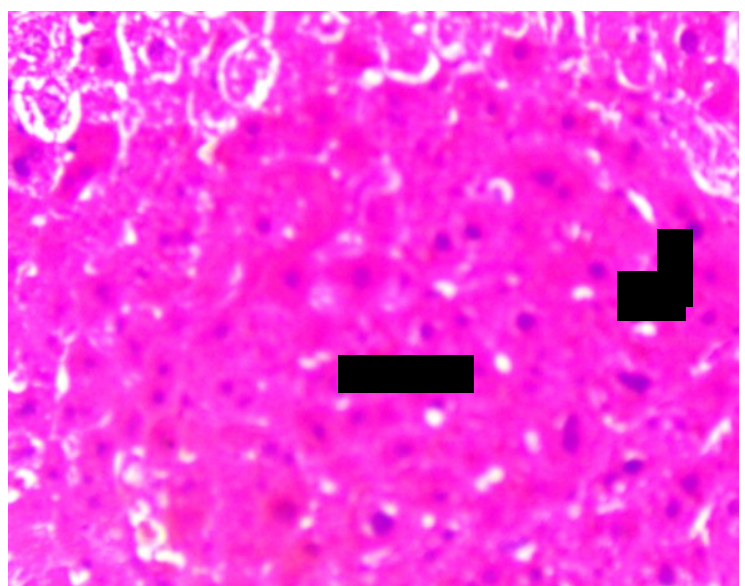

Fig. 9. Shows liver section $2.8 \mathrm{mg} / \mathrm{kg} \mathrm{N}$. glauca treated mice. Large area of necrosis. (H\&E, X400).

Lung Histopathology: The terminal bronchioles of lung tissues are composed of air (alveolar) sacs with a space known as alveolus. Alveoli are separated by alveolar wall which is composed of fibrous tissues and epithelial cells (pneumocytes) and blood vessels, which were observed in the lung section of control female mice (Fig. 10).

In the $0.25 \mathrm{mg} / \mathrm{kg}$ treated mice, focal interstitial inflammation (Fig. 11), and in the $0.50 \mathrm{mg} / \mathrm{kg}$ treated mice, interstitial inflammation and cellular hyperplasia of the alveolar wall were observed (Fig.12).In the $2.8 \mathrm{mg} / \mathrm{kg}$ treated mice, dilation of air space (emphysema) was observed (Fig.13).Emphysema occurs due to elastic damage (resulting from the release of elastase enzyme by inflammatory cells).

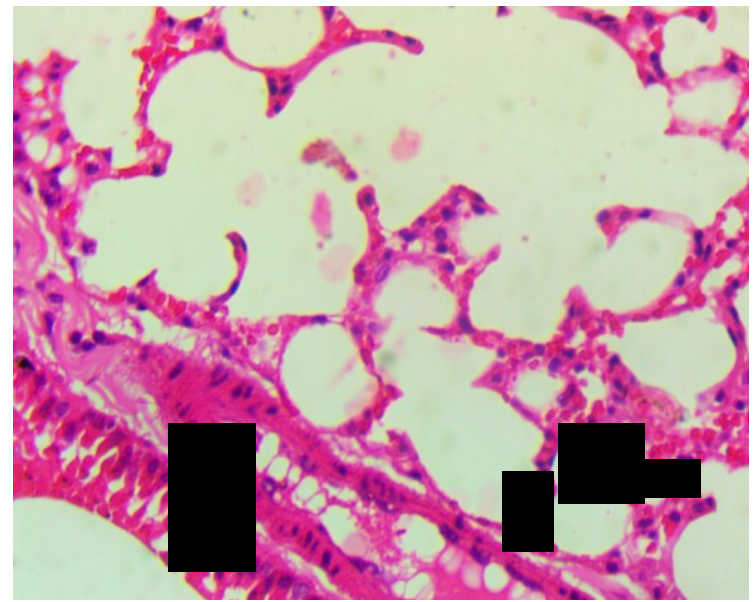

Fig. 10. Shows lung section in control, the normal alveolar with a space known as alveolus and blood vessels. (H\&E, X400).

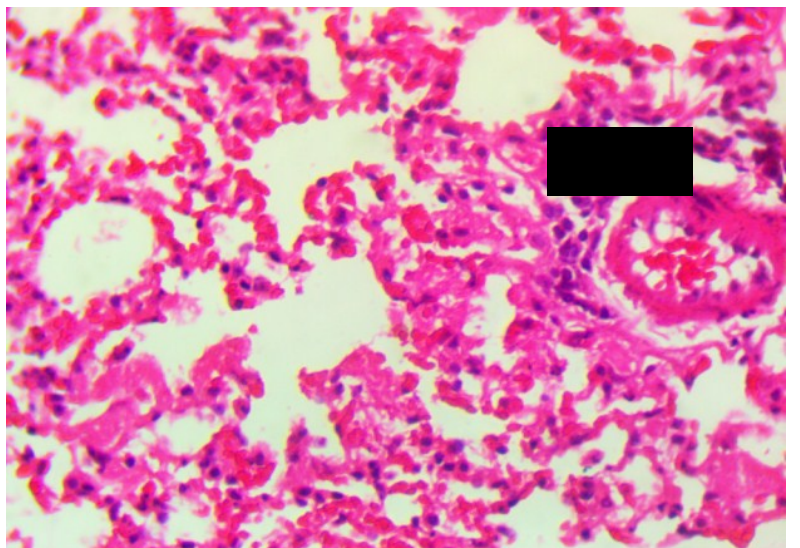

Fig. 11. Shows lung section in $0.25 \mathrm{mg} / \mathrm{kg} N$. glauca treated mice, focal interstitial inflammation $(\mathrm{H} \& \mathrm{E}$, X400).

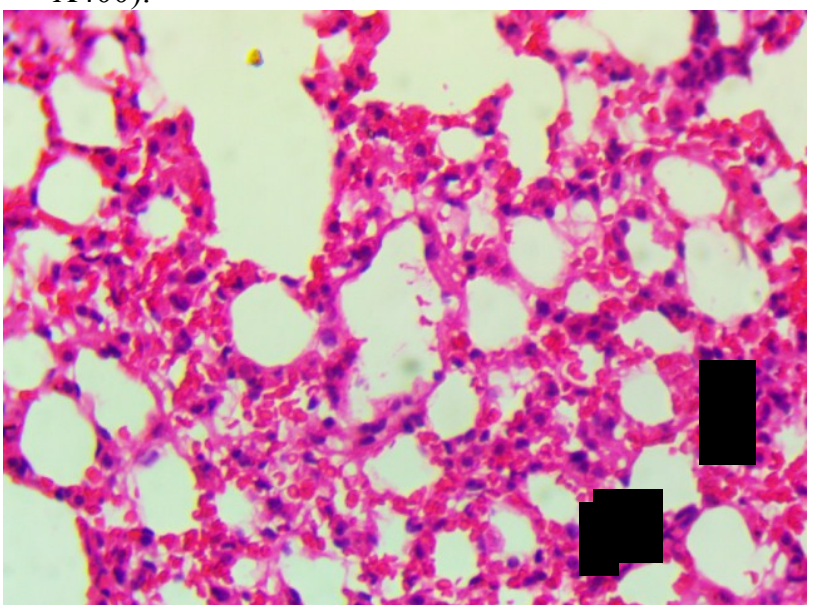

Fig. 12. Shows lung section in $0.50 \mathrm{mg} / \mathrm{kg} \mathrm{N}$. glauca treated mice, focal interstitial inflammation and cellular hyperplasia of alveolar wall (H\&E, X400).

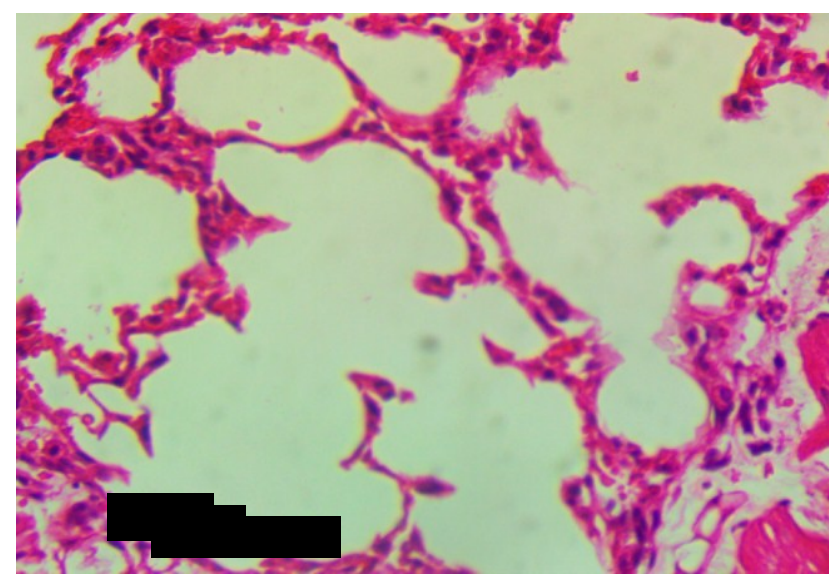

Fig. 13. Shows lung section $2.8 \mathrm{mg} / \mathrm{kg} N$. glauca treated mice, emphysema (H\&E, X400).

(C) 2020 The Author(s). This open access article is distributed under a CC BY-NC 4.0 license. ISSN: online 2617-2186 print 2617-2178 


\section{DISCUSSION}

Anabasine, nicotine, and other few glycosides are produced by the tree tobacco Nicotiana glauca. Poisoning by anabasine is characterized by nicotine-like toxicity. The clinical effects of nicotine alkaloid toxicity are the result of the stimulation actions at ganglionic sites, motor endplates, and smooth muscle (Schep et al., 2009). Nicotine alkaloids initially stimulate the ganglia of the sympathetic and parasympathetic nervous systems by direct cholinomimetic action on the ganglia. This is quickly followed by prolonged ganglionic blockade due to persistent depolarization. A similar action occurs at the neuromuscular junction causing total paralysis of skeletal muscles and subsequent respiratory failure. Death occurs from respiratory failure due to peripheral blockage of the muscles of respiration (Manoguerra and Freeman, 1982). The results of female mice body weight observed in this study confirm the previously reported cases, where, the percentage change of $N$. glauca treated mice body weight was significantly or numerically lower than that of control. This reduction in the weight of mice following treatment can be attributed to depression, diarrhea, weakness, and vomiting, as these were among the evident signs of symptoms observed on the treated mice. These results have also been confirmed by the findings of (Wilson and DeEds, 1936 and Rowell et al., 1983).

The effects of $N$. glauca water leaf extract on blood parameters and blood chemistry have shown relatively elevated values of $\mathrm{WBC}$, RBC, Hb, HCT, PLT, and MCV for blood parameters and Urea, Creatinine, $\mathrm{Na}^{+}, \mathrm{k}^{+}$, Total protein and ALT for blood chemistry, in comparison with the standard range. However, no such changes in these values were detected between the lower $N$. glauca doses treated and non-treated female mice in the experimental animals in this study. This finding could mean that $N$. glauca extract has not induced direct toxicological effects on blood parameters and blood chemistry when used at low doses. How- ever, (Saneck et al., 1994) have not reported significant alterations in clinical chemical values for the vitreous (blood urea nitrogen, creatinine, chloride, sodium, potassium, calcium, magnesium, and phosphorus).

Lack of previous studies concerning this part of toxicity, however, made it difficult to give any further elaboration for now.

Histological sections from the liver and lung of $N$. glauca treated female mice showed inflammation and necrosis, particularly in the liver and lung. No other severe pathological effects could be detected in either of the tissues examined, where, hepatocytes showed more vacuoles (hydropic degeneration) and necrotic cells in the treated mice liver and interstitial inflammation, cellular hyperplasia of alveolar wall, and emphysema that occurs due to elastic damage resulting from the release of elastase enzyme by inflammatory cells in the treated mice lung. These findings were confirmed by (Saneck et al., 1994) who found that lesions in mules had induced severe, diffuse swelling of renal proximal tubular epithelial cells. Whereas, centrilobular hepatocytes had undergone a mild fatty change and necrosis, in scattered foci. Pulmonary alveoli contained moderate quantities of proteinaceous fluid and rare red blood cells. Myocardial cells had undergone diffuse, mild swelling.

Damage to the structural integrity of the liver is reflected by an increase in the liver hepatospecific enzymes in alkaline phosphate (ALP), Alanine Aminotransferase (ALT) and Aspartate Aminotransferase (AST) in the serum because they are cytoplasmic in location and are released into circulation after cellular damage (Janbaz and Gilani, 1995).

The liver represents the primary site of metabolism of nicotine, although the lung and kidney also contribute to metabolism.

On average, $30 \%$ of the nicotine that enters the liver exits unchanged, and $70 \%$ leaves the liver in the form of metabolites. Events that change the hepatic flow, such as eating, posture, and 
exercise, reduce hepatic blood flow, and reduce the rate of nicotine metabolism (Benowitz and Jacob, 1997).

Renal clearance of unmetabolized nicotine depends on urinary $\mathrm{pH}$ and can account for 2-35 $\%$ of nicotine excretion. Nicotine is reabsorbed from the proximal tubules, where the $\mathrm{pH}$ is high.

Anabasine, the plant's main active ingredient, can cause severe systemic intoxication due to its nicotinic receptor agonist action, with respiratory muscle paralysis being the main effect (Ntelios et al., 2013).

Nicotine is absorbed via intact skin, oral mucosa, the GI tract, and the respiratory system. It is detoxified mainly in the liver, and also the kidneys and lungs. The major metabolic product of nicotine is cotinine. Cotinine, along with a nonmetabolized form of nicotine, is excreted in the urine. Elimination is complete in $16 \mathrm{~h}$; however, acidic urine increases urinary excretion. Nicotine is also excreted in the milk of lactating women (Gupta, 2016).

\section{CONCLUSION}

Prolonged exposure of female Swiss albino mice to concentrations of the water extract $(0.25,0.50$, and $2.8 \mathrm{mg} / \mathrm{kg})$ has evidently resulted in bodyweight reduction, liver and lung congestion, and enlargement.

Histopathological examination revealed an early sign of inflammation and cell necrosis of the liver and lung, as well as the accumulation of leucocytes in both.

\section{ACKNOWLEDGEMENT}

The authors would like to thank Allah for his blessing and his help in completing this study. We would like to acknowledge Dr. Abd EiGafer El-Mnfi for his help with the statistical analysis. We would also like to thank all faculty members, technicians, and employees of the Zoology department.

\section{REFERENCES}

Alder, L. S., Seifert M. G., Wink. And Morse, G. E. (2012). Reliance on pollinators predicts defensive chemistry across tobacco species. Ecol. Lett., 15: 11401148.

Benowitz, N. L. and Jacob, P. III. (1997). Individual differences in nicotine kinetics and metabolism in humans [Review]. Natl. Inst. Drug Abuse. Res. Monogr., 173: 48-64.

Goodman, L. S. and Gilman, A. (1985). The Pharmacological Basis of Therapeutics. $7^{\text {th }}$ Edition, MacMillan Publishing Co., New York.

Gosseline, R. E., Smith, R. H. and Hodge, H. C. (1984). Nicotine In :Clini. Cal. Toxicology of Commerical products Fifth Edition, Williams and wikins, Baltimor, Maryland, Williams andwikins, Baltimor, Maryland, pp. III-311-314.

Gupta, P. K. (2016). Toxic effects of cardiac poisons. in Fundamentals of toxicology. 21.4.

Janbaz, K. H. and Gilani, A. H. (1995). Evaluation of the protective potential of Artemisia maritime extraction acetaminophen- and CCl4-induced liver damage. J. Ethnopharmacol., 47: 43-47.

Long, N., Ren, X., Xiang, Z., Wan, W. and Dong, Y. (2016). Sequencing and characterization of leaf transcriptomes of six diploid Nicotiana species. J. Biol. Res., (Thessalon). 23: 6.

Manoguerra, A. S. and Freeman, D. (1982). Acute poisoning from the ingestion of Nicotianaglauca. J. Toxicol. Clin. Toxicol. 19: 861-864.

Melamed, H. T., Markman, S., Aieli, A., Dist, M., Wink, M. and Tzhaki, I. (2004). 
Limited ability of Palestine sunbirds Nectarinia osea to cope with pyridine alkaloids in necter of tree tobacco Nicotiana glauca. Func. Ecol., 18: 844-850.

Mellick, L. B., Makowski, T., Mellick, G. A. and Borger, R. (1999). Neuromuscular blockade after ingestion of tree tobacco (Nicotiana glauca). Ann. Emerg. Med., 34: 101-104.

Mitchell, J. W. and Breyer-Brandwijk, E. (1962) Medicinal and poisonous plants of southern and Eastern Africa- $2^{\text {nd }}$ ed. and S livingston; 986.

Ntelios, D., Kargakis, M., Topalis, T., Drouzas, A. and Potolidis, E. (2013). Acute respiratory failure due to Nicotiana glauca ingestion. Hippokartia., 17 (2): 183184.

Panter, K. E., James, L. F. and Gardner, D. R. (1999). Lupines, poison hemlock and Nicotiana ssp.: toxicity and teratologenicity in livestock. J. Nat. Toxins., 8 (1):117-134.

Preece, A. H. (1972). Amanual for Histologic Technicians, $4^{\text {th }}$ ed. (227-231). Little, Brown and company. Boston.

Rotenberg, K. S. (1982). The pharmacokinetics of nicotine. Pharm. Int., 3: 91-93.

Rowell, P. P., Hurst, H. E., Marlowe, C. and Bennett, B. D. (1983). Oral administration of nicotine: Its uptake and distribution after Chronic administration to mice. J. Pharmacol. Methods, 9: 249261.

Saneck, R., Gupta, R. C. and Kadel, W. L. (1994). Lethal nicotine intoxication in a group of mules. J. Vet. Diagn. Invest.,6: 503-504.
Schep, L. J., Slaughter, R. J. and Beasley, D. M. (2009). Nicotinic plant poisoning. Clin. Toxicol. (Phila.), 47: 771-781.

Schievelbein, H. and Balfour, D. J. K. (1984). Nicotine, reabsorption and fate. In: Nicotine and the smoking Habit, international Encylopedia of pharmacology and Therapeutics, Section 114, Pergamon Press, New, York., pp. 1-12.

Sokal, R. R. and Rodlf, F. F.(1969) Biometry, the principle of statistics in biological research. W. H. freeman and company, san fransisco, USA.

Webb, M. and Dalzell, S. (1997) Nicotiana glauca toxicity. Emergency. Med., 9: 25-28.

Wilson, R., \& DeEds, E. (1936). Chronic nicotine toxicity. I. Feeding of nicotine sulfate, tannate, and bentonite. J. Int. Hyg. Toxicol, 18, 553-564.

Wink, M. (2000). Interference of alkaloids with neuroreceptors andionchannels. Bioactive Natural Products, Vol. 11 (ed. Atta-Ur-Rahman), pp. 3-129. Elsevier Science, Amsterdam. 
تأثثر مستخلص أولق نبات التبغ على كبد ورئة إناث الفئران السويسرية البيضاء: دراسة فسيولوجية ونسيجية مرضية

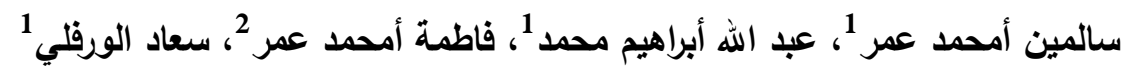

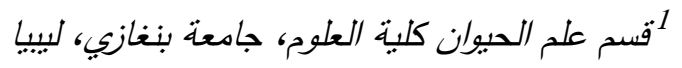

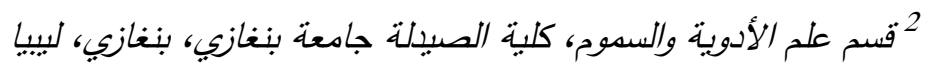

تاريخ الاستلام: 01 سبتمبر 2019 / تاريخ القبول: 22 أغسطس 2020 (c) مجلة المختار للعلوم 2020

https://doi.org/10.54172/mjsc.v35i2.302:Doi

المستخلص: نبات التبخ البري Nicotiana glauca هو عضو من العائلة الباذنجانية ويوجد في المناطق الاستوائية وشبه

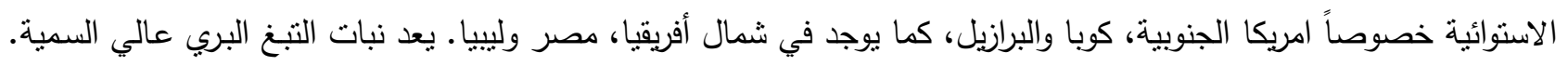

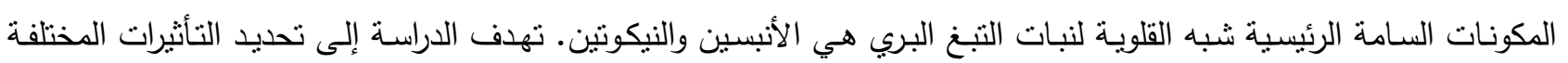

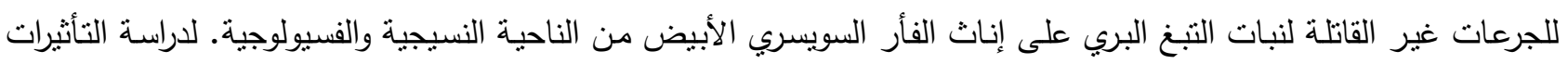

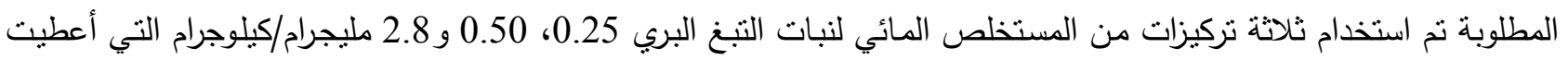

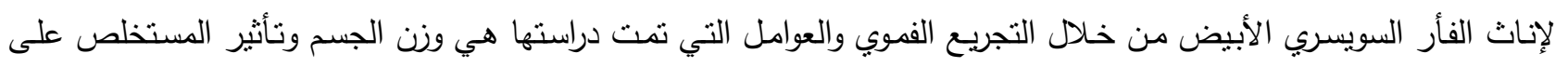

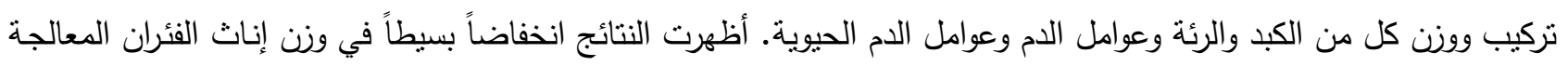

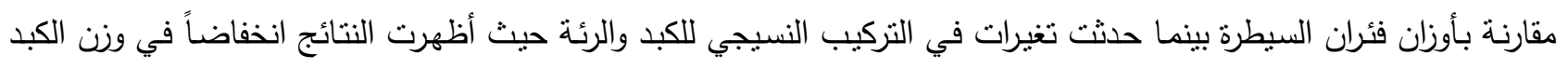

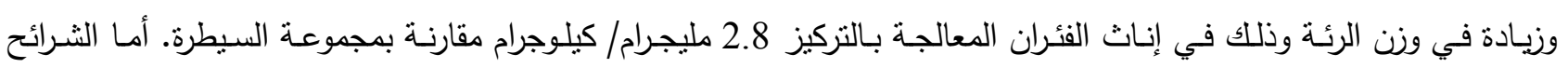

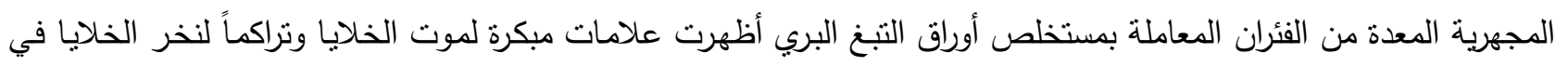

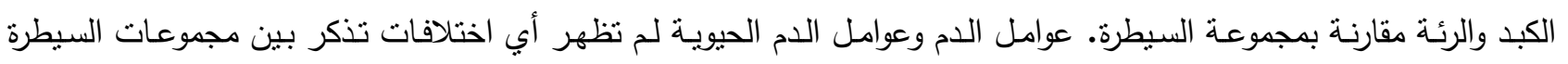

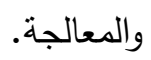

الكلمات المفتاحية: التبغ البري، إناث الفأر، فسيولوجي، علم الأنسجة مرضية. 